\title{
SPATIAL AND TEMPORAL VARIATION OF TOTAL AND TROPOSPHERIC OZONE COLUMNS OVER CHINA
}

\author{
Xin Li, Yingjie Li*, Qingmiao Ma, Jing Chen, Fang Chen, Xinyue Yang, Qianjie Wang \\ School of Geography, Geomatics and Planning, Jiangsu Normal University, 101 Shanghai Road, \\ Tongshan District, Xuzhou 221116, China - lixinjsnu@163.com, liyingjiejsnu@yahoo.com, maqingmiaojsnu@yahoo.com, \\ chenj0829@126.com,1219698334@qq.com,1299122043@qq.com,1628966501@qq.com
}

\section{Commission III, WG III/8} KEY WORDS: Total Ozone Column, Tropospheric Ozone Column, Spatial Distribution, Long Temporal Variation, AERONET,
OMI

\begin{abstract}
:
In this study, total ozone columns collected from nine sites of the AErosol RObotic NETwork (AERONET) in China are used to evaluate total ozone column monthly mean products of the Ozone Monitoring Instrument (OMI). The results show the correlated coefficient of the two datasets is 0.95 . The long temporal variations and spatial distributions of the monthly mean products of the total ozone columns and tropospheric ozone columns in spring, summer, autumn and winter were plotted. The result shown in the pictures indicate that the total ozone columns gradually increase from low latitude to high latitude, reach the maximum value in winter and spring in Northeast China, and the values in Qinghai-Tibet Plateau are lower than those of other regions of the same latitude. The monthly mean of total ozone columns at low latitude have no obvious seasonal variation. With the increase of latitude, the seasonal variation of monthly mean products of total ozone column becomes more and more obvious. Tropospheric ozone columns are the highest in summer, followed by spring and autumn, and the lowest in winter, which are mainly concentrated in the more developed areas in eastern China. The lowest value of tropospheric ozone column in China occurs in the Qinghai-Tibet Plateau in winter and the highest value in North China in summer. The study indicates that the total ozone columns vary with latitude while tropospheric ozone columns are more susceptible to human activities and natural conditions.
\end{abstract}

\section{INTRODUCTION}

Ozone high in the atmosphere screens out biologically harmful solar ultraviolet radiation, keeping it from reaching the surface. Such ultraviolet radiation is destructive of genetic cellular material in plants and animals, as well as human beings. Because most of the ozone in our atmosphere is contained in the stratosphere, we refer to this region as the stratospheric ozone layer. In contrast to beneficial stratospheric ozone, tropospheric ozone is a pollutant found in high concentrations in smog. Though it too absorbs ultraviolet rays (UV) radiation, breathing it in high levels is unhealthy, even toxic. The high reactivity of ozone results in damage to the living tissue of plants and animals. This damage by heavy tropospheric ozone pollution is often manifested as eye and lung irritation. So the monitoring of ozone is of great significance. Although there are many satellite instruments for ozone measuring from space, the observations differ in spatial resolution, local time of measurement, viewing geometry, and other details (Hilboll et al. 2013). Therefore, the ground measurements are irreplaceable. The aims of the study are to evaluate the total ozone column monthly mean data of OMI using ozone average daily data collected form AERONET sites and analyse the long temporal variations and spatial distributions of the ozone over China.

\section{DATA AND METHOD}

\subsection{Study Area}

The spatial range of the study area is $73^{\circ}-135^{\circ} \mathrm{E}$ and $3^{\circ}-$ $53^{\circ} \mathrm{N}$. Most of the study area is in the temperate zone, while a small part of the study area is in the tropical zone, and there is no cold zone in the study area. In this area, nine sites of the AERONET were selected for the analysis, which are: AOE_Baotou, Beijing, Chen-Kung_Univ, Hong_Kong_PloyU, NAM_CO, QOMS_CAS, SACOL, Taihu and XuZhou-CUMT. The spatial distributions of the sites were plotted in Figure 1, and informations of the sites were shown in Table 1.

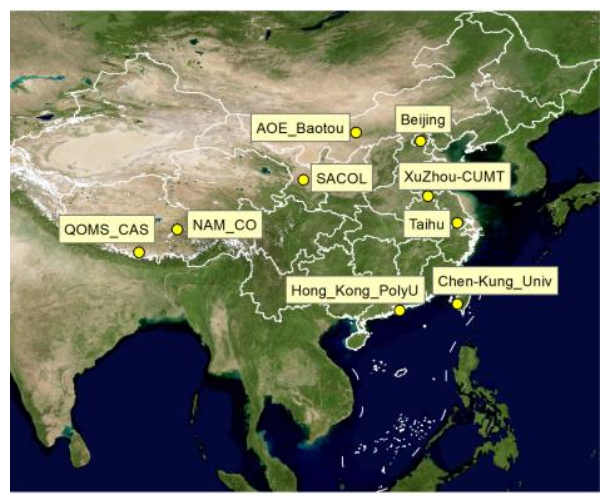

Figure 1. AERONET sites distributions in the study area

\subsection{Datasets}

The ground-measured ozone dataset was collected from the AERONET, which were retrieved from the measurements of the CE318-T Sun-Sky-Lunar spectral photometer using the Version 3 direct Sun and inversion algorithms (Barreto et al. 2016; Giles et al. 2018). There are three levels of AERONET

\footnotetext{
* Corresponding author: liyingjiejsnu@ yahoo.com
} 
operational standard product: Level 1.0 (unscreened with possible cloud contamination), Level 1.5 (cloud screened), and Level 2.0 (cloud screened and quality assured) (Zhang et al. 2016). The data can be obtained from http://aeronet.gsfc.nasa.gov/. The Level-2.0 data of the AERONET sites are preferred. If the Level-2.0 data are not available, the Level-1.5 data are selected instead.

The OMI instrument is a nadir looking instrument which measures the radiation backscattered by the Earth's atmosphere and surface over the entire wavelength range from 270 to 500 $\mathrm{nm}$, with a spectral resolution of about $0.5 \mathrm{~nm}$. The American predecessor of OMI is National Aeronautics and Space Administration (NASA)'s Total Ozone Meteorological Satellite
(TOMS) instrument. OMI combines the advantage of Global Ozone Monitoring Experiment (GOME) and TOMS, measuring the complete spectrum in the ultraviolet/visible wavelength range with a very high spatial resolution $(13 \times 24 \mathrm{~km})$ and daily global coverage (Levelt and Noordhoek, 2002; Zhang et al. 2016). The total ozone column monthly data are based on OMDOAO3 v.1.1.1.1 which is processed with the ozone and cloud algorithm versions 1.0.1, Operation Parameter File (OPF) version 31 and Ground Data Processing Software (GDPS) version 0.9.15 (Hassinen et al. 2008). The Royal Netherlands Meteorological Institute's (KNMI) near real time (NRT) ozone are also based on the same Differential Optical Absorption Spectroscopy-Method (DOAS) algorithm as the OMDOAO3 product.

\begin{tabular}{ccccccc}
\hline \hline Site Name & $\begin{array}{c}\text { Latitud } \\
\mathrm{e}\end{array}$ & $\begin{array}{c}\text { Longitude } \\
\left({ }^{\circ}\right)\end{array}$ & $\begin{array}{c}\text { Elevation } \\
(\mathrm{m})\end{array}$ & Data Level & $\begin{array}{c}\text { Start Date } \\
\text { dd-mm-yyyy) }\end{array}$ & $\begin{array}{c}\text { End Date } \\
(\text { dd-mm-yyyy })\end{array}$ \\
\hline AOE_Baotou & 40.852 & 109.629 & 1314 & 1.5 & $25-09-2013$ & $14-12-2018$ \\
Beijing & 39.977 & 116.381 & 92 & 2.0 & $14-10-2005$ & $10-06-2018$ \\
Chen-Kung_Univ & 22.993 & 120.205 & 50 & 2.0 & $02-01-2005$ & $30-09-2018$ \\
Hong_Kong_PolyU & 22.303 & 114.180 & 30 & 2.0 & $04-11-2005$ & $28-03-2017$ \\
NAM_CO & 30.773 & 90.962 & 4746 & 2.0 & $06-08-2006$ & $01-08-2016$ \\
QOMS_CAS & 28.365 & 86.948 & 4276 & 2.0 & $18-10-2009$ & $16-11-2017$ \\
SACOL & 35.946 & 104.137 & 1965.8 & 2.0 & $28-07-2006$ & $06-05-2013$ \\
Taihu & 31.421 & 120.215 & 20 & 2.0 & $01-09-2005$ & $23-08-2016$ \\
XuZhou-CUMT & 34.217 & 117.142 & 59.7 & 1.5 & $28-06-2013$ & $31-12-2018$ \\
\hline \hline
\end{tabular}

Table 1. Informations of nine AERONET sites used in this study

\subsection{Method}

In this study, the total ozone columns of OMI were compared with the AERONET measurements. The monthly mean total ozone columns of all points at nine sites from AERONET are calculated, which are used to compare with that obtained from satellites. The reliability of satellite total ozone column monthly mean products are verified by scatter plots of ground- measured data of AERONET sites and satellite data. Then the monthly total ozone column at the selected sites from both satellite and ground observations were plotted, as well as the spatial distribution maps of the satellite product over China in the spring, summer, autumn and winter. The trend of total ozone column was analyzed form 2005 to 2018, while that of tropospheric ozone column was analyzed form 2004 to 2017.

\section{RESULT}

\subsection{Satellite Product Evaluation}

The scatters between the ground and the satellite ozone contents were plotted in Figure 2. The total numbers of matches between time of nine sites and OMI are 834. The results show that the total ozone columns of OMI are more consistent with the AERONET data. A good agreement is found between the total ozone columns of AERONET and OMI. The correlated coefficient (R) is 0.95, the Root Mean Squared Error (RMSE) is 4.11 Dobson Unit (DU) and the slop of the linear fitting equation is 0.921 , which indicates that the OMI total ozone column values are of high reliability.

\subsection{Long Temporal Variations of Total Ozone Column}

The monthly mean of OMI total ozone column and the AEROENT data at the selected sites were plotted in Figure 3. It can be found that at the site of SACOL, which are located in the West China, most total ozone column values of both satellite and ground observations are more than $300 \mathrm{DU}$, and at AOE_Baotou, the values are generally more than 300 DU. At NAM_CO and QOMS_CAS, the values are generally less than 300 DU because of the high altitude. However, in the North and East China, e.g. at the sites of Beijing, XuZhou-CUMT and Taihu, where the economic is developing very fast, the values of total ozone column from both AERONET and OMI are almost vary within the interval of 300-400 DU, and the maximum values can even exceed $400 \mathrm{DU}$ in some seasons. For the sites of Chen-Kung_Univ and Hong_Kong_PloyU, which are located in the tropical zone and the natural conditions here are conducive to the diffusion of pollutants, both satellite and ground observations are less than 300 DU. Trends of OMI total ozone columns in nine sites were presented in Table 2.

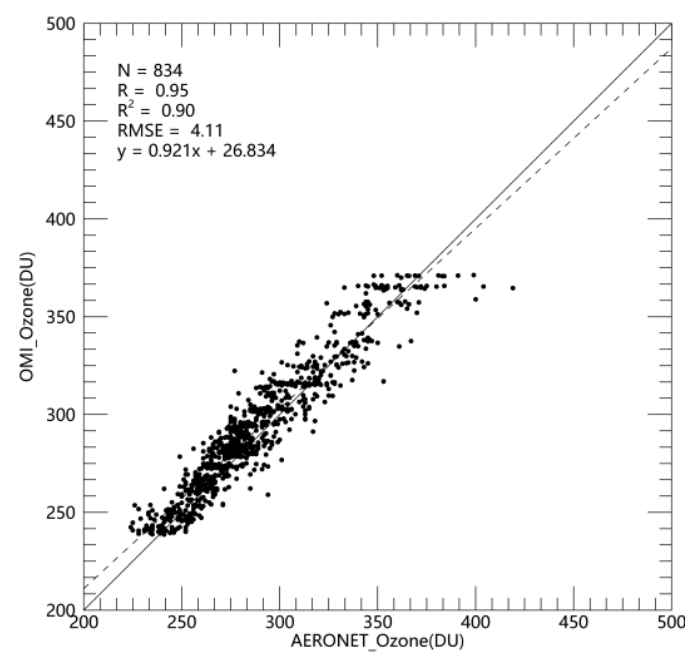


Figure 2. Correlations between the AERONET Ozone and the OMI total ozone column
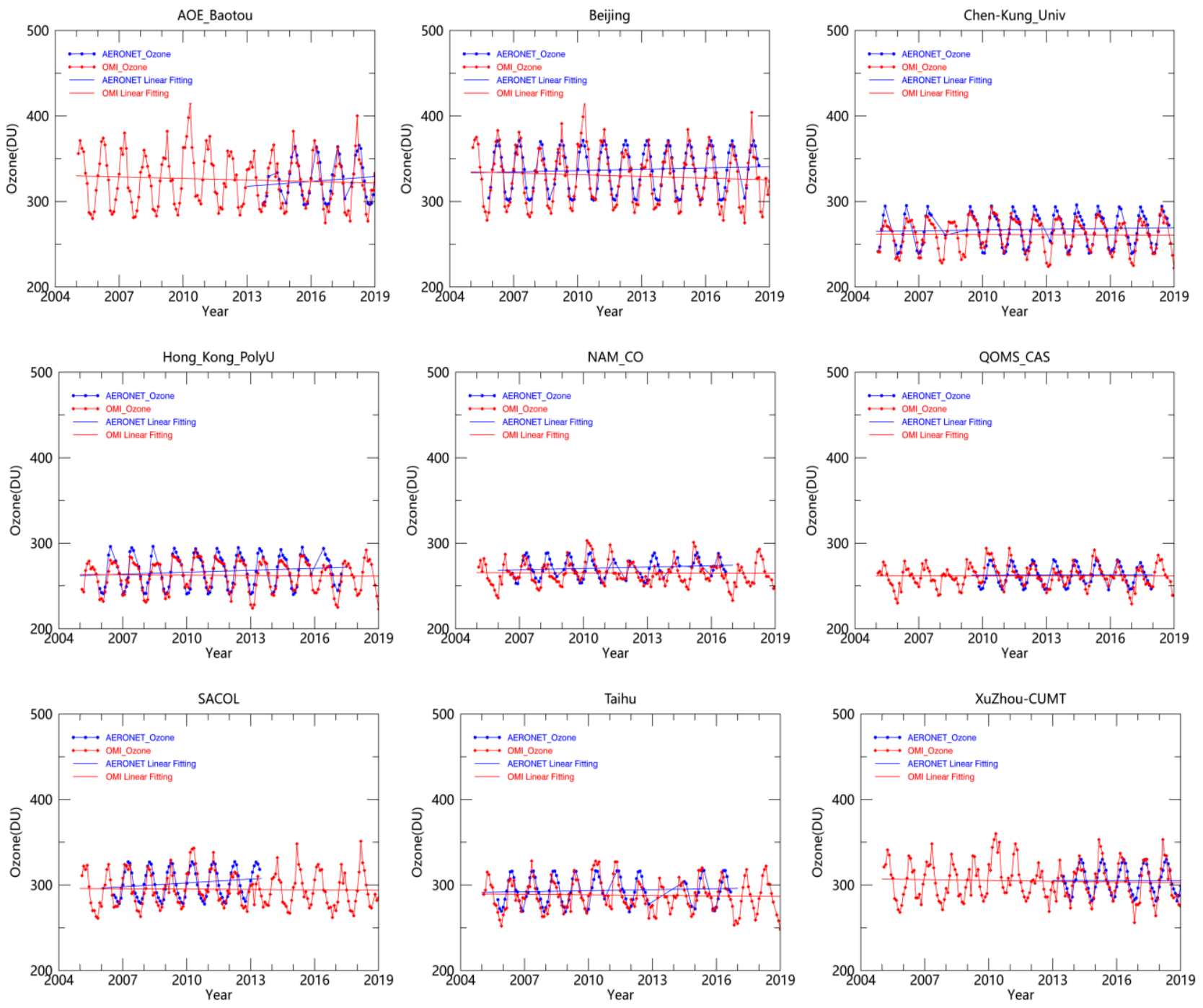

\begin{tabular}{ccccc}
\hline \hline Site Name & $\begin{array}{c}\text { Period } \\
\text { (yyyy- yyyy })\end{array}$ & $\begin{array}{c}\text { Linear Fitting } \\
(\text { AERONET })\end{array}$ & $\begin{array}{c}\text { Period } \\
(\text { yyyy }- \text { yyyy })\end{array}$ & $\begin{array}{c}\text { Linear Fitting } \\
(\text { OMI })\end{array}$ \\
\hline AOE_Baotou & $2013-2008$ & $\mathrm{y}=0.876 \mathrm{x}-249.1510$ & $2005-2018$ & $\mathrm{y}=-0.601 \mathrm{x}+1535.575$ \\
Beijing & $2005-2018$ & $\mathrm{y}=-0.118 \mathrm{x}+575.456$ & $2005-2018$ & $\mathrm{y}=-0.667 \mathrm{x}+1671.909$ \\
Chen-Kung_Univ & $2005-2018$ & $\mathrm{y}=0.297 \mathrm{x}-330.3170$ & $2005-2018$ & $\mathrm{y}=-0.083 \mathrm{x}+428.9010$ \\
Hong_Kong_PolyU & $2005-2017$ & $\mathrm{y}=0.301 \mathrm{x}-339.3730$ & $2005-2018$ & $\mathrm{y}=-0.140 \mathrm{x}+544.5260$ \\
NAM_CO & $2006-2016$ & $\mathrm{y}=0.183 \mathrm{x}-94.92700$ & $2005-2018$ & $\mathrm{y}=-0.048 \mathrm{x}+362.6050$ \\
QOMS_CAS & $2009-2017$ & $\mathrm{y}=0.198 \mathrm{x}-135.1370$ & $2005-2018$ & $\mathrm{y}=-0.005 \mathrm{x}+271.7030$ \\
SACOL & $2006-2013$ & $\mathrm{y}=1.502 \mathrm{x}-2714.503$ & $2005-2018$ & $\mathrm{y}=-0.141 \mathrm{x}+577.8700$ \\
Taihu & $2005-2016$ & $\mathrm{y}=0.116 \mathrm{x}+60.00500$ & $2005-2018$ & $\mathrm{y}=-0.214 \mathrm{x}+718.3390$ \\
XuZhou-CUMT & $2013-2018$ & $\mathrm{y}=-0.064 \mathrm{x}+436.685$ & $2005-2018$ & $\mathrm{y}=-0.318 \mathrm{x}+944.1800$ \\
\hline \hline
\end{tabular}

Figure 3. Monthly variation of the total ozone columns derived from satellite and ground observations at the study sites

Table 2. Schematic table of linear fitting equation from 2005 to 2018 at the nine sites 


\subsection{Long Temporal Variation of Tropospheric Ozone Column}

Variation of tropospheric ozone columns were plotted in Figure 4 and the trends of OMI trop ozone column in different seasons at selected sites were shown in Table 3. The tropospheric ozone columns are the highest in summer, followed by spring and autumn, and the lowest in winter. It is mainly concentrated in the more developed areas in eastern China. In spring, the distribution of tropospheric ozone columns in China tends to be more southeast than northwest, and the tropospheric ozone columns in the south of the Yangtze River is relatively high. The main reason is that the south of the Yangtze River is densely populated and industrially developed. Ozone produced by man-made occupies a dominant position. Volatile organic compounds and nitrogen oxides emitted from industrial exhaust and automobile exhaust generate ozone under the action of sunlight. Except for the Qinghai-Tibet Plateau and YunnanGuizhou Plateau, the tropospheric ozone columns in summer are generally higher in China. This is mainly due to the high temperature and strong solar radiation in summer in China. To withstand the scorching heat, more energy is used and nitrogen oxides are produced in all parts of the country. In the north of China, when the temperature rises and the wheat harvest season is just in time, a large number of straw incineration will also lead to the generation of polluted gases, which makes the North China area more polluted.

The distribution of tropospheric ozone column in autumn is lower than that in spring and summer in China, showing a trend of more in northeast and less in southwest. The high value region of the tropospheric ozone columns are mainly distributed in the plains of the middle and lower reaches of the Yangtze River, North China Plain and Sichuan Basin. Because the middle and lower reaches of the Yangtze River are densely populated and industrially developed, volatile organic compounds and nitrogen oxides emitted from industrial exhaust and automobile exhaust generate ozone under the action of sunlight. When rice is harvested in the South and spring wheat in the North China Plain, straw burns to produce polluting gases while wheat is harvested. Sichuan Basin is also a high value area because of its low middle terrain and high surrounding area, and the decrease of precipitation in autumn, which makes ozone gas difficult to diffuse. Northwest China has a relatively low value because of its small population, slow industrial development, low temperature and basically animal husbandry.

In winter, the distribution of tropospheric ozone column in China is the lowest in four seasons. Ozone concentration in most parts of the country is low because of the weak solar radiation. The middle and lower reaches of the Yangtze River and Northeast China have relatively high values. Because of the cold climate in Northeast China, centralized heating began in winter, and coal combustion led to the increase of anthropogenic ozone in the air. The population of the middle and lower reaches of the Yangtze River is concentrated and the industry is developed, which makes the ozone higher. The ozone value of the Qinghai-Tibet Plateau reaches its minimum in one year.
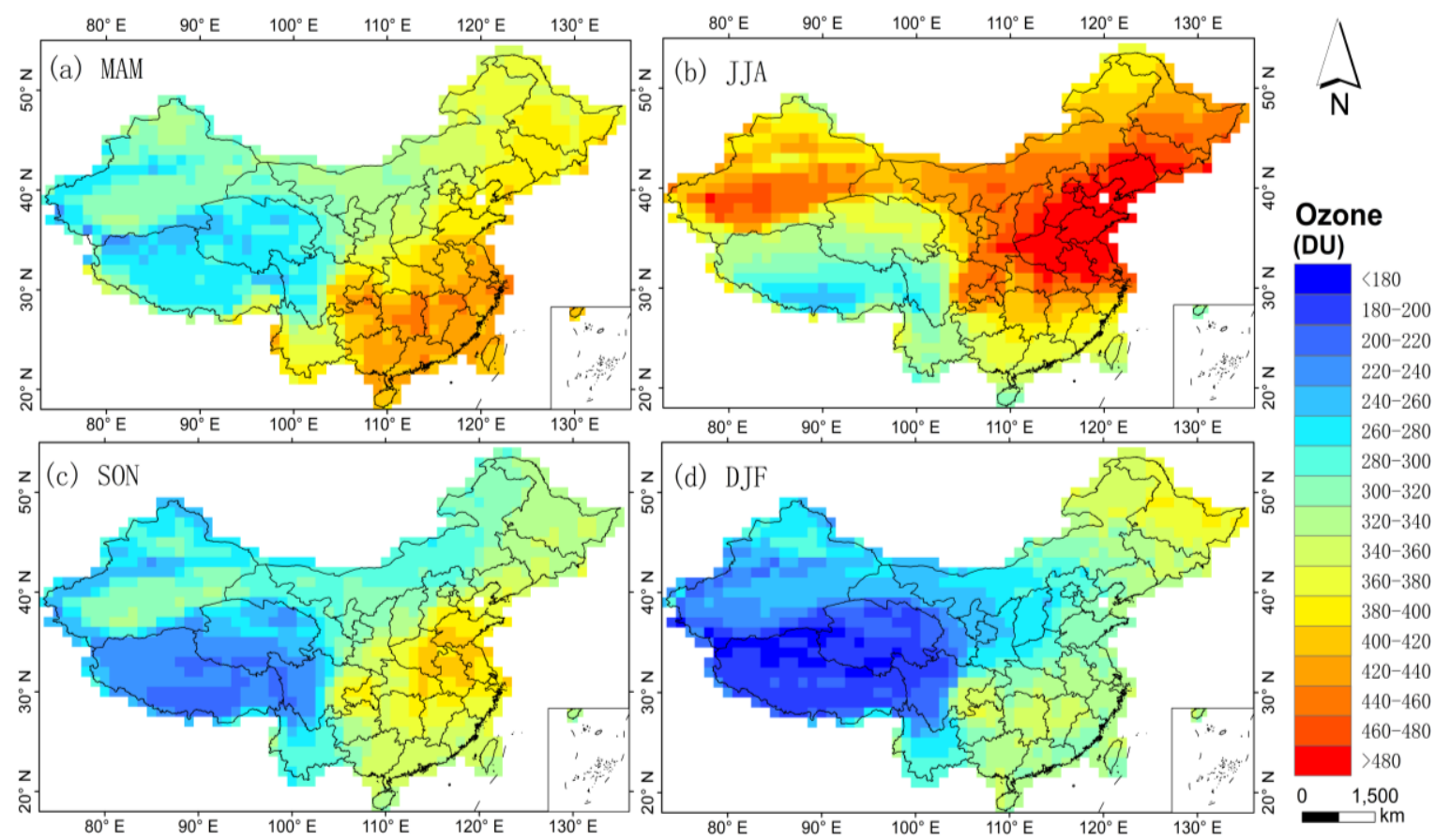

Figure 4. Seasonal variation of tropospheric ozone column over China from 2004 to 2017

\subsection{Long Temporal Variation of Total Ozone Column}

The distribution of total ozone column is basically the same in the four seasons, showing a more obvious zonal distribution, gradually increasing from low latitude to high latitude, and the peak value of total ozone column appears in the northeast of China, while the total ozone columns in the Qinghai-Tibet Plateau and southeast of China is lower (Figure 5). Generally speaking, the monthly mean of total ozone columns in low latitudes has no obvious seasonal variation. In winter and spring, the total ozone columns in low latitudes are lower than that in summer and autumn. In winter, the highest value of total ozone columns appeared in the northeast of China, and the lowest value appeared in the south of Yunnan Province, Hainan Island and southern Taiwan. It can be seen that the seasonal variation of total ozone columns is more obvious in high latitude areas. 
The main reason is the seasonal variation of solar radiation, especially the seasonal variation of solar ultraviolet radiation, which is the key factor of ozone photolysis in the atmosphere. Therefore, the variation of ozone produced by the photolysis of oxygen is also large. The regional distribution of total ozone columns in spring are basically the same as that in winter, but the difference between the total ozone columns in spring and that in the same latitude is smaller. In summer, the total ozone columns do not change significantly, and there is no obvious high value area. Compared with the same latitude, the lowest value area is located in the Qinghai-Tibet Plateau of China, which is mainly due to the topography.
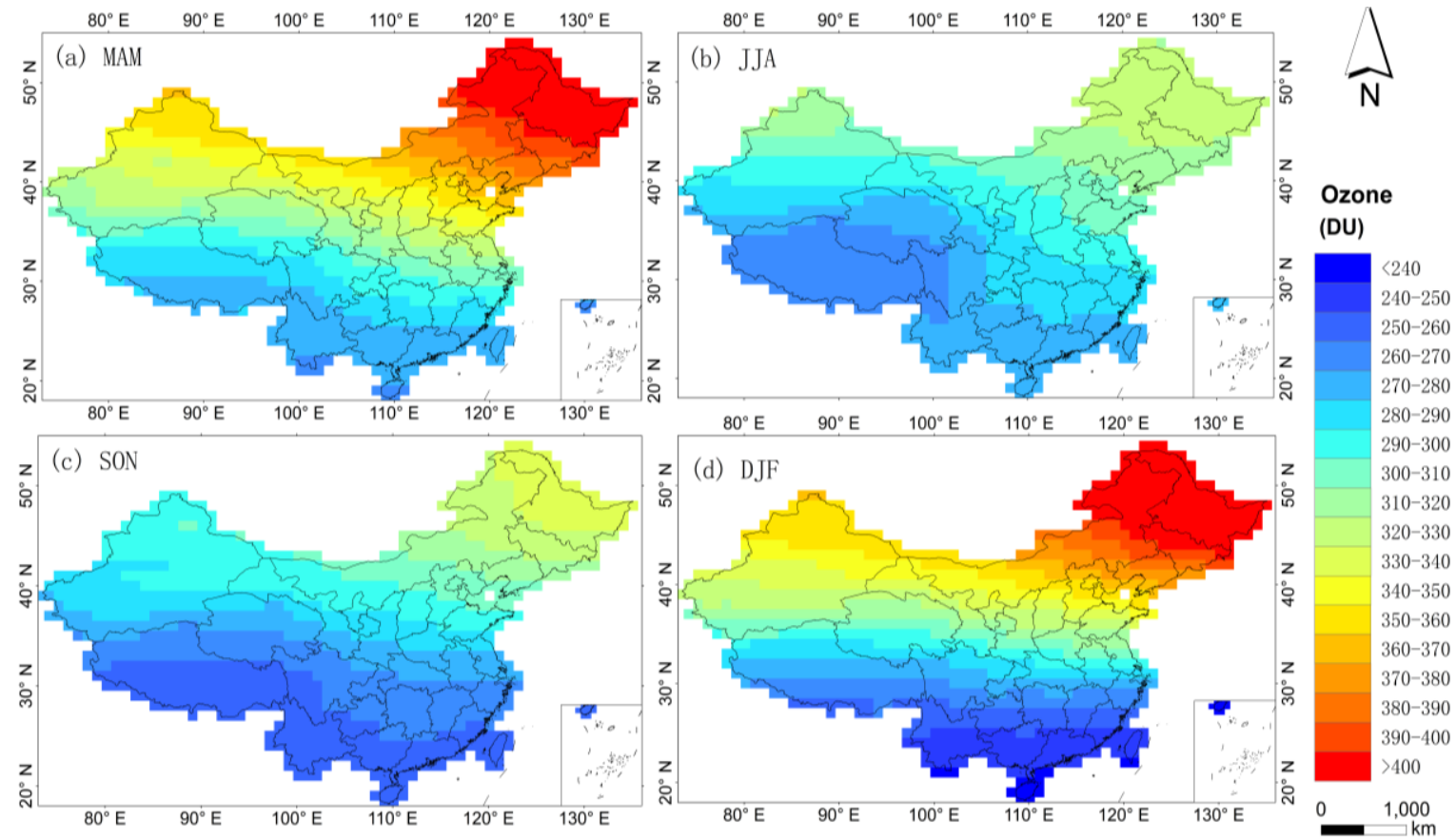

Figure 5. Seasonal variation of total ozone column over China from 2005 to 2018

\section{CONCLUSION}

In this study, the datasets of Ozone contents over China from OMI/MLS and AERONET were collected, evaluated, plotted, calculated and analyzed. Some conclusions can be drawn as below.

(1) The evaluation results show that OMI total ozone column datasets are correlated with the AERONET ozone contents, whit R of 0.95 , Root Mean Squared Error (RMSE) of 4.11 DOBSON. The slop of the linear fitting equation is 0.921 .

(2) The long temporal analysis and the spatial distribution maps indicate that the values of tropospheric ozone column are the highest in summer, followed by spring and autumn, and the lowest in winter, it's mainly concentrated in the more developed areas in eastern China.

(3) The study indicates that the highest total ozone column value occurs in the high latitudes of China, and the total ozone column value in the high latitudes of spring is higher than that in winter. In summer and autumn, compared with the same latitude areas, there are obvious low total ozone column values in the Qinghai-Tibet Plateau region of China. In the high latitudes of China, the highest total ozone column value appears in spring and the lowest in autumn.

(4) Human activities generally affect the ozone content in the troposphere, where ozone pollution mostly occurs in. Ozone pollution often occurs in industrially developed and densely populated economically developed areas. Ozone pollution will be more serious in summer.

\section{ACKNOWLEDGMENTS}

This work was supported by the Postgraduate Research \& Practice Innovation Program of Jiangsu Normal University under Grant No. 2019XKT057, and the Postgraduate Research \& Practice Innovation Program of Jiangsu Province under Grant No. KYCX18_2155.

The authors would like to acknowledge the Tropospheric Emission Monitoring Internet Service (TEMIS), the Royal Netherlands Meteorological Institute (KNMI), National Aeronautics and Space Administration (NASA) for providing ozone products, and the principal investigators (PIs) and their staff of the sites: AOE_Baotou, Beijing, Chen-Kung_Univ, Hong_Kong_PloyU, NAM_CO, QOMS_CAS, SACOL, Taihu and XuZhou-CUMT, for establishing and maintaining the AERONET sites used in this investigation.

\section{REFERENCES}

Barreto, A., Cuevas, E., Granados-Munoz, M. J., Alados Arboledas, L., Romero, P. M., Grobner, J., Kouremeti, N., Groebner, J., Kouremeti, N., Almansa, A. F., Stone, T., Toledano, C., Roman, R. Sorokin, M., Holben, B., Canini, M., Yela, M., 2016. The new sun-sky-lunar Cimel CE318-T multiband photometer - a comprehensive performance evaluation. Atmospheric Measurement Techniques, 9(02), 631654 .

Giles, D. M., Sinyuk, A., Sorokin, M. S., Schafer, J. S., Smirnov, A., Slutsker, I., Eck, T. F., Holben, B. N., Lewis, J., 
Campbell, J., Welton, E. J., Korkin, S., Lyapustin, A., 2018. Advancements in the Aerosol Robotic Network (AERONET) version 3 database - automated near real-time quality control algorithm with improved cloud Screening for Sun photometer aerosol optical depth (AOD) measurements. Atmospheric MeasurementTechniques, https://doi.org/10.5194/amt-2018272 , in review.

Hassinen, S., Tamminen, J., Tanskanen, A., Leppelmeier, G., Malkki, A., Koskela, T., Karhu, J. M., Lakkala, K., Veefkind, P.,

Krotkov, N., Aulamo, O., 2008. Description and validation of the OMI very fast delivery products. Journal of Geophysical Research-Atmospheres, 113(D10).

Hilboll, A., Richter, A., Burrows, J. P., 2013. Long-term changes of tropospheric NO2 over megacities derived from multiple satellite instruments. Atmospheric Chemistry and Physics, 13(08), 4145-4169.

Levelt, P. F., Noordhoek, R., 2002, OMI Algorithm Theoretical Basis Document - Volume I - OMI Instrument - Level 0-1b processor. Calibration \& Operations, Version 1.1, 5-7, http://projects.knmi.nl/omi/documents/data/OMI_ATBD_Volu me_1_V1d1.pdf

Zhang, W., Gu, X., Xu, H., Yu, T., Zheng, F., 2016. Assessment of OMI near-UV aerosol optical depth over Central and East Asia. J. Geophys. Res. Atmos. 121, 382-398.

\begin{tabular}{|c|c|c|c|}
\hline $\begin{array}{l}\text { AERONET } \\
\text { sites }\end{array}$ & Seasons & Linear Fitting & $\mathrm{R}$ \\
\hline \multirow{4}{*}{ AOE_Baotou } & MAM & $y=3.828 x-7373.938$ & 0.3109 \\
\hline & JJA & $y=0.475 x-501.040$ & 0.0503 \\
\hline & SON & $y=0.107 x+86.336$ & 0.0079 \\
\hline & DJF & $\mathrm{y}=1.969 \mathrm{x}-3685.275$ & 0.2290 \\
\hline \multirow{4}{*}{ Beijing } & MAM & $y=1.747 x-3137.365$ & 0.1493 \\
\hline & JJA & $y=0.866 x-1236.013$ & 0.0848 \\
\hline & SON & $y=1.595 x-2856.814$ & 0.1026 \\
\hline & DJF & $y=1.714 x-3149.042$ & 0.1739 \\
\hline \multirow{4}{*}{ Chen-Kung_Univ } & MAM & $y=2.226 x-4072.488$ & 0.1753 \\
\hline & JJA & $y=1.867 x-3418.506$ & 0.2570 \\
\hline & SON & $y=-0.114 x+559.666$ & -0.0190 \\
\hline & DJF & $\mathrm{y}=2.197 \mathrm{x}-4109.047$ & 0.3097 \\
\hline \multirow{4}{*}{ Hong_Kong_PolyU } & MAM & $\mathrm{y}=1.144 \mathrm{x}-1889.438$ & 0.1189 \\
\hline & JJA & $y=1.024 x-1708.639$ & 0.1550 \\
\hline & SON & $y=0.227 x-109.377$ & 0.0325 \\
\hline & DJF & $y=0.519 x-728.585$ & 0.0356 \\
\hline \multirow{4}{*}{ NAM_CO } & MAM & $y=-1.766 x+3810.544$ & -0.0784 \\
\hline & JJA & $y=2.143 x-4036.470$ & 0.2478 \\
\hline & SON & $y=2.315 x-4442.312$ & 0.4599 \\
\hline & DJF & $y=1.653 x-3125.237$ & 0.2413 \\
\hline \multirow{4}{*}{ QOMS_CAS } & MAM & $y=-3.154 x+6607.420$ & -0.1085 \\
\hline & JJA & $y=-2.166 x+4501.913$ & -0.0529 \\
\hline & SON & $y=3.008 x-5829.895$ & 0.4331 \\
\hline & DJF & $y=-0.460 x+1098.414$ & -0.0309 \\
\hline \multirow{4}{*}{ SACOL } & MAM & $y=2.349 x-4403.694$ & 0.1705 \\
\hline & JJA & $y=-0.100 x+615.637$ & -0.0106 \\
\hline & SON & $y=1.270 x-2254.046$ & 0.1123 \\
\hline & DJF & $y=1.267 x-2315.701$ & 0.1320 \\
\hline \multirow{4}{*}{ Taihu } & MAM & $y=0.565 x-698.301$ & 0.0335 \\
\hline & JJA & $y=3.698 x-6973.236$ & 0.2693 \\
\hline & SON & $y=0.505 x-616.599$ & 0.0511 \\
\hline & DJF & $y=3.239 x-6175.503$ & 0.3070 \\
\hline \multirow{4}{*}{ XuZhou-CUMT } & MAM & $\mathrm{y}=1.874 \mathrm{x}-3351.362$ & 0.1419 \\
\hline & JJA & $y=2.828 x-5156.819$ & 0.3300 \\
\hline & SON & $y=0.010 x+391.800$ & 0.0014 \\
\hline & DJF & $y=3.527 x-6781.103$ & 0.3656 \\
\hline
\end{tabular}

Table 3. Trend analysis of annual trop ozone column in different seasons from 2004 to 2017 at nine sites. 